\title{
Clinical and histomorphometrical study on titanium dioxide-coated external fixation pins
}

This article was published in the following Dove Press journal:

International Journal of Nanomedicine

4 February 2013

Number of times this article has been viewed

\section{Hironobu Koseki' \\ Tomohiko Asahara' \\ Takayuki Shida' \\ Itaru Yoda' \\ Hidehiko Horiuchi' \\ Koumei Baba ${ }^{2}$ \\ Makoto Osaki'}

'Department of Orthopedic Surgery, Graduate School of Medicine, Nagasaki University, ${ }^{2}$ Industrial Technology Center of Nagasaki, Nagasaki, Japan
Correspondence: Hironobu Koseki Department of Orthopedic Surgery, Graduate School of Medicine, Nagasaki University, I-7-I, Sakamoto, Nagasaki 852-850I, Japan

$\mathrm{Tel}+8 \mid 958197321$

Fax +8I 958497325

Email ji20 I 10043@cc.nagasaki-u.ac.jp
Background: Pin site infection is the most common and significant complication of external fixation. In this work, the efficacy of pins coated with titanium dioxide $\left(\mathrm{TiO}_{2}\right)$ for inhibition of infection was compared with that of stainless steel control pins in an in vivo study.

Methods: Pins contaminated with an identifiable Staphylococcus aureus strain were inserted into femoral bone in a rat model and exposed to ultraviolet A light for 30 minutes. On day 14, the animals were sacrificed and the bone and soft tissue around the pin were retrieved. The clinical findings and histological findings were evaluated in 60 samples.

Results: Clinical signs of infection were present in $76.7 \%$ of untreated pins, but in only $36.7 \%$ of $\mathrm{TiO}_{2}$-coated pins. The histological bone infection score and planimetric rate of occupation for bacterial colonies and neutrophils in the $\mathrm{TiO}_{2}$-coated pin group were lower than those in the control group. The bone-implant contact ratio of the $\mathrm{TiO}_{2}$-coated pin group was significantly higher $(71.4 \%)$ than in the control pin group (58.2\%). The $\mathrm{TiO}_{2}$ was successful in decreasing infection both clinically and histomorphometrically.

Conclusion: The photocatalytic bactericidal effect of $\mathrm{TiO}_{2}$ is thought to be useful for inhibiting pin site infection after external fixation.

Keywords: titanium dioxide, external fixation, bactericidal activity, Staphylococcus aureus

\section{Introduction}

External fixation has gained wide acceptance in osteotomy, limb lengthening, and treatment of open fractures because it enables easy reduction of bone fragments, even under unfavorable soft tissue conditions, and secondary corrections and modifications can be made. ${ }^{1}$ Despite these positive qualities, there is still a high incidence of pin site infection, which may cause mechanical deterioration of the bone-pin interface and lead to pin loosening and osteomyelitis..$^{2-6}$ Pin site infection is due to indigenous micro-organisms adhering to the pin surface and subsequently forming aggregates that may lead to formation of a biofilm and eventual spread of infection to the surrounding host tissue. Reported rates of pin site infection vary widely in the literature, ranging from virtually zero to over $50 \%$. $^{3,5,6}$ Generally, the cleaning and/or dressing of pin sites and systemic antibiotics are used for prevention and treatment of pin site infection. ${ }^{3,6}$ However these anti-infection measures have limitations. Pins with deep infection should be removed and suppression of infection must be given priority, which means that continuation of treatment with external fixation for the primary disease becomes impossible.

An additional problem arising from pin site infection is the risk of deep tissue infection, such as osteomyelitis, when converting external fixation to internal fixation, 
because of penetration of the skin barrier. ${ }^{7}$ Therefore, a new strategy for prevention and treatment of pin site infection is required.

Modifications to biomaterial surfaces enable programming of cells to substratum events, thereby diminishing infection by inhibiting bacterial adhesion or by enhancing tissue compatibility or integration. Recent studies by other groups have investigated the bactericidal effects of silver and antibiotics used as coatings for metal materials. ${ }^{8-13}$ However, Massè et al aborted a study of the clinical application of silver-coated pins due to elevated blood levels of silver ions. ${ }^{9}$ Furno et al concluded that the clinical failure of silver is mainly due to obliteration by proteinaceous materials in the human body. ${ }^{10}$ Development of bacterial resistance to silver coating has also been reported. ${ }^{11}$ Another group demonstrated the antibacterial effect of pins impregnated with tobramycin or gentamicin in an animal model. However, there are still concerns about the side effects of these agents and the emergence of resistant strains of bacteria. ${ }^{12,13}$

The bactericidal activity of photocatalytic titanium dioxide $\left(\mathrm{TiO}_{2}\right)$ has recently been highlighted as an alternative strategy to assist in environmental purification of water and air because of its high catalytic activity, chemical stability, low energy requirements, and nontoxic properties. ${ }^{14,15}$ Pure titanium and titanium alloys are widely used in modern orthopedic surgery because of their high resistance to corrosion and their biocompatibility. $\mathrm{TiO}_{2}$ photocatalysts have strong oxidizing ability and can decompose various organic compounds when exposed to ultraviolet light by generating active oxygen species, such as free hydroxyl radicals, superoxide anion radicals, and hydrogen peroxide. This photodecomposition of organic compounds is also useful for killing bacteria, so selfsterilizing surfaces can be prepared. It has been confirmed that these active oxygen species can destroy the outer bacterial cell membrane, ultimately leading to nonselective cell death without fostering drug-resistant species, as well as decompose endotoxins and provide nourishment for bacteria. ${ }^{16-20}$ In our previous in vitro studies, $\mathrm{TiO}_{2}$ film had a strong photocatalytic bactericidal effect on Staphylococcus aureus, ${ }^{21}$ which is one of the main bacteria causing pin site infection and can easily become antibiotic-resistant. ${ }^{9,22-24}$ Arciola et al found that S. aureus accounted for about $68 \%$ of bacteria isolated from infected incision sites postoperatively. ${ }^{22} \mathrm{TiO}_{2}$ can act as a potent biocidal agent because of its high oxidation potential and nonselective reactivity, so we hypothesized that a $\mathrm{TiO}_{2}$ photocatalyst might reduce the risk of harmful pin site infection and then conducted an in vitro experiment. The purpose of the current in vivo study was to evaluate the efficacy of photocatalytic $\mathrm{TiO}_{2}$ in inhibition of infection when using percutaneous external fixation pins in a rat model under low energy ultraviolet illumination.

\section{Materials and methods Preparation of implant materials}

The substrates were prepared using $2 \mathrm{~mm}$ diameter pin screws (Atlas Sports and Medicine Co, Ltd, Nagasaki, Japan) made of stainless steel (SUS316L) which is the basic material in external fixation pins. The native oxides were removed by cleaning the samples with distilled water and acetone and then immersing them in a mixture of aqueous $\mathrm{HF}$ and $\mathrm{HNO}_{3}$ acids. The plasma source ion implantation apparatus used in this study has been described elsewhere. ${ }^{21,25}$ This implantation method has several advantages compared with other methods, including a large area, multiple targets, and reasonable costs. $\mathrm{TiO}_{2}$ films were deposited onto the stainless steel pins using titanium tetraisopropoxide plasma in the chamber. A pulsed high negative bias voltage of $-18 \mathrm{kV}$ was applied to the sample holder at a pulse duration of $10 \mu \mathrm{sec}$ with a pulse repetition rate of $1 \mathrm{kHz}$. The pin was annealed at $923 \mathrm{~K}$ for one hour to obtain a crystalline anatase $\mathrm{TiO}_{2}$ film. The pins were divided into two groups (30 control pins and 30 pins coated with $\mathrm{TiO}_{2}$ ). Glancingangle X-ray diffraction patterns for the $\mathrm{TiO}_{2}$ pins showed peaks at positions corresponding mainly to an anatase-type structure, including a rutile one, and X-ray photoelectron spectroscopy revealed the chemical composition was almost all $\mathrm{TiO}_{2}$. Energy-dispersive spectroscopy indicated that the homogeneous microstructure was composed of titanium, oxygen, and elements of stainless steel. Crosssectional analysis of the $\mathrm{TiO}_{2}$ layers revealed an average thickness of $1.0 \mu \mathrm{m}$, with no interfaces evident between the substrate and the dense layer. The surface roughness parameters for $\mathrm{TiO}_{2}$-coated stainless steel $(\mathrm{Ra}=808 \mathrm{~nm}$, $\mathrm{Rz}=1674$ ) were almost the same as for untreated stainless steel $(\mathrm{Ra}=837 \mathrm{~nm}, \mathrm{Rz}=1755)$, as reported in our previous study. ${ }^{21}$ Micrographs of the surfaces of the $\mathrm{TiO}_{2}$-coated pins were obtained using a field emission scanning electron microscope (JSM 6400F, JEOL, Tokyo, Japan).

\section{Evaluation of bactericidal effect}

This series of in vivo experiments was performed in accordance with the principles stated in the established guidelines for the treatment of animal subjects, and animal welfare assurance was strictly maintained. S. aureus (Seattle 1945 strain, ATCC 25923) was incubated for 6 hours at $37^{\circ} \mathrm{C}$ 
in $10 \mathrm{~mL}$ of trypticase soy broth. The bacterial cells were harvested by centrifugation at $3000 \mathrm{rpm}$ for 10 minutes and then suspended in sterilized distilled water to a concentration of $1 \times 10^{8}$ cells $/ \mathrm{mL}$. Sixty female, 7 -week-old SpragueDawley (specific pathogen-free) rats were obtained from Charles River Laboratories Japan Inc, Yokohama, Japan. The animals were housed individually in a secure, climatecontrolled facility for the duration of the experiment.

The operative procedure was performed under general anesthesia by intraperitoneal administration of a sodium pentobarbital ( $50 \mathrm{mg} / \mathrm{kg}$ of body weight). The insertion areas on the hind limb of each animal were shaved, and the area over the femur was aseptically prepared with $70 \%$ ethanol. A small linear skin incision (about 1-2 mm) was made and the pins were inserted through the incision into the femoral bones (one pin per bone), followed by bacterial contamination with $100 \mu \mathrm{L}$ of an identifiable $S$. aureus strain on the insertion area, ie, the skin-pin interface. Ultraviolet A light was emitted using a black light source set $30 \mathrm{~cm}$ above the rats for 30 minutes. In our previous in vitro study, the $\mathrm{TiO}_{2}$-coated material significantly suppressed the viability of bacteria after 30 minutes of ultraviolet illumination, ${ }^{21}$ so the illumination time was set to 30 minutes. The intensity of the light was $2.0 \mathrm{~mW} / \mathrm{cm}^{2}$ at a peak wavelength of $352 \mathrm{~nm}$. Each rat was then extubated and allowed to recover in its cage. The pin sites were examined daily and the dressings were carefully changed to avoid cross-contamination of the pin sites. Additional treatment, including incision closure, blood coagulation, or antibiotic dressing was not needed. On day 14, visible clinical findings at each pin site were classified according to pin site infection criteria as no infection, inflammation or serous drainage without frank purulence, or frank purulence. ${ }^{26,27}$ Clinical determination of infection was defined as all three observers being in agreement. After evaluation by eye, the animals were sacrificed and the bone and soft tissue around the pin were retrieved. We used an automated microbiology system (BD Phoenix ${ }^{\mathrm{TM}}$ System, Nippon Becton Dickinson Co, Tokyo, Japan) to identify the bacteria isolated (panel type PMIC/ID-68). The tissues obtained were fixed for one day in a $10 \%$ formalin solution buffered at $\mathrm{pH} 7.2$, dehydrated through a series of graded alcohol solutions, and embedded in paraffin. Immediately after removal of the pins, $4 \mu \mathrm{m}$ thick longitudinal sections in the sagittal plane were cut using a microtome (HM325, Thermo Scientific Mircom, Walldorf, Germany) with a 40 degree stainless steel knife, taking care not to damage the bone-implant interface. The slices were stained with hematoxylin and eosin and Gram-stained. Slices in the same bone plane were assessed according to bone infection score as: 1) abscess formation; 2) sequestrum formation; 3 ) enlargement of corticalis; 4) destruction of corticalis; and 5) general appearance. ${ }^{12,28}$ Parameters 1 to 4 were scored as 0 (absent) or 1 (present). Parameter 5 was scored as 0 (absent), 1 (mild), or 2 (severe). The test samples had a maximum score of 6 . We then computed the rate of contact between bone and screw, on the assumption that the part in which it is possible to confirm the shape of a screw thread in the tissue specimen is the part contacted, based on a modification of the method reported by Giavaresi et al and Moroni et al..$^{29,30}$ We did the actual image processing of the hematoxylin and eosin staining sample automatically using an optical microscope (BX51-33, Olympus Optical Co, Tokyo, Japan) connected to public domain image analysis software (Image J) and computed the data. In addition, the shape of the bone for the part corresponding to a screw thread was evaluated by Gram staining. We first chose a part in which it was possible to confirm the two consecutive screw threads from the entrance part of a pin screw and then made a planimetric rate of occupation for bacterial colonies and intraosseous neutrophils in the shape of a screw thread using Image $\mathrm{J}$. The clinical and histomorphometric results for the control group $(n=30)$ were analyzed and compared with those of the $\mathrm{TiO}_{2}$-coated pin group $(\mathrm{n}=30)$.

\section{Statistical analyses}

All statistical analyses were performed using the Statistical Package for Social Sciences version 20 software (SPSS Inc, Chicago, IL). The clinical findings were analyzed using the Chi-square test. The mean and standard deviation of bone infection score, bone-implant contact ratio, and planimetric rate of occupation for bacterial colonies and intraosseous neutrophils were analyzed using the Student's $t$-test. Statistical significance was set at 0.01 .

\section{Results}

Figure 1 shows a scanning electron micrograph of the surface of $\mathrm{a} \mathrm{TiO}_{2}$ pin. The $\mathrm{TiO}_{2}$ surface had a number of global microstructures with diameters of 1-2 $\mu \mathrm{m}$ and were well separated and homogeneously distributed over the sample. These structures were not seen on the untreated pin.

No operative or postoperative complications were encountered. All of the animals tolerated surgery well and survived until the end of the experiment. Clinical evaluation revealed purulence and/or serous drainage in 23 of the 30 control pins $(76.7 \%)$, compared with only 11 of the $30 \mathrm{TiO}_{2}$ pins $(36.7 \%, P<0.01)$, as shown in Table 1 . 


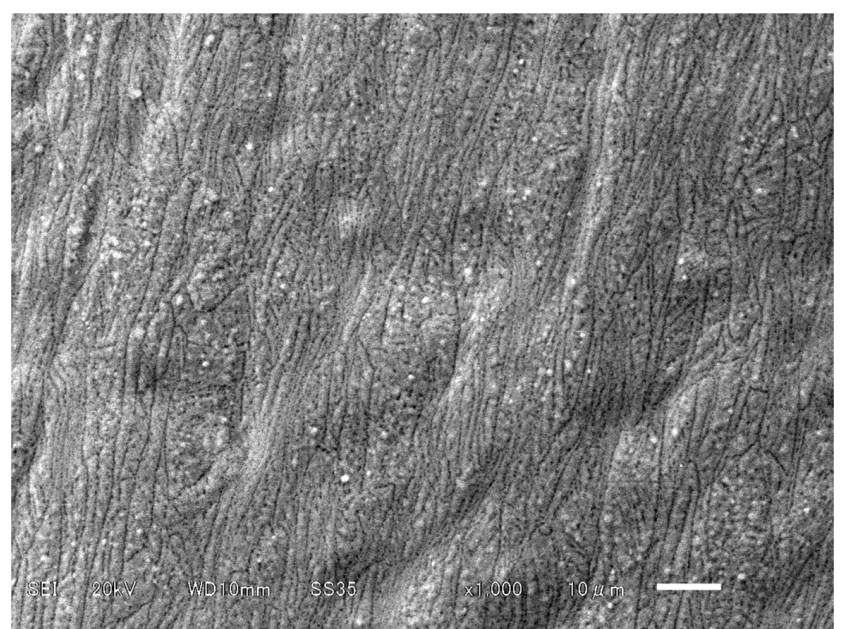

Figure I Scanning electron micrograph of the surface of a $\mathrm{TiO}_{2}$-coated pin. Notes: Photocatalyst nanoparticles adhering to the surface of the $\mathrm{TiO}_{2}$ are observed. Original magnification $\times 1000$ (scale bar $10 \mu \mathrm{m})$.

Abbreviation: $\mathrm{TiO}_{2}$, titanium dioxide.

The automated microbiology system identified the microorganisms isolated from the purulence or drainage around the infected pin as being the same strain as that from the initial pin inoculation. Histological images from the two groups are shown in Figure 2. Severe bone resorption and destruction caused by infection were seen in the control pin group, whereas the $\mathrm{TiO}_{2}$ pin was directly in contact with bone tissue, and new vessels and osteoblast cells were seen. The histomorphometric findings are summarized in Table 2. The mean bone infection score for the $\mathrm{TiO}_{2}$ pins was significantly lower than that for the control pins $(3.1 \pm 1.6$ points versus $4.9 \pm 1.0$ points, $P<0.01)$. The mean bone-implant contact ratio for the untreated stainless steel pin group was $58.2 \% \pm 8.1 \%$, whereas the $\mathrm{TiO}_{2}$ pin group showed a mean ratio of $71.4 \% \pm 5.4 \%$. The rate of contact in the control pin group was significantly lower than in the $\mathrm{TiO}_{2}$-coated pin group $(P<0.01)$. In the group of untreated pins, many areas of bacterial colonies and intraosseous neutrophils were seen. The planimetric rate of occupation for bacterial colonies and intraosseous neutrophils in the shape of a screw thread was $24.7 \% \pm 10.3 \%$ for the control pins and $13.3 \% \pm 6.4 \%$ for

Table I Evaluation of clinical findings according to criteria for pin site infection

\begin{tabular}{lllll}
\hline & $\begin{array}{l}\text { Infection } \\
(-)\end{array}$ & $\begin{array}{l}\text { Inflammation, } \\
\text { drainage }\end{array}$ & $\begin{array}{l}\text { Pus } \\
\text { discharge }\end{array}$ & Total \\
\hline Untreated pin & $7(23.3 \%)$ & $16(53.3 \%)$ & $7(23.3 \%)$ & 30 \\
$\mathrm{TiO}_{2}$ pin & $19(63.3 \%)$ & $9(30.0 \%)$ & $2(6.7 \%)$ & 30 \\
\hline
\end{tabular}

Notes: Signs of infection, purulence, and/or serous drainage were significantly more common in the control pin group than in the $\mathrm{TiO}_{2}$-coated pin group $(76.7 \%$ versus $36.7 \%, P<0.01$ ).

Abbreviation: $\mathrm{TiO}_{2}$, titanium dioxide. the $\mathrm{TiO}_{2}$-coated pins, so the rate of occupation for the group of $\mathrm{TiO}_{2}$ pins was significantly lower $(P<0.01)$.

\section{Discussion}

Pin site infection with external fixation can easily occur by contiguous spreading, ie, commensal skin bacteria pass subcutaneously along the surface of the device towards the internal tissues. Infected pins may lead to pin loosening, need for pin removal, and chronic osteomyelitis, which is considered to be a risk factor for deep infection in the conversion to internal fixation..$^{2-4,7}$ In terms of treatment, much money and time are needed, in addition to the distress caused to patients. Although various studies have been conducted to develop antibacterial external fixation pins, there remain concerns about the side effects of the agents used and emergence of resistant bacteria. Hence we tested the photocatalytic anti-infective activity of $\mathrm{TiO}_{2}$ in a rat model of external fixation. $\mathrm{TiO}_{2}$ mainly consists of three polymorphs, ie, anatase, rutile, and brookite. Using different methods and conditions, single or multiple polymorphs can be formed, with various morphologies. Anatase is the most photocatalytic polymorph and generates many free radicals, which can decompose bacteria and other organic compounds via its strong oxidative effects. ${ }^{14,15}$ Therefore, anatase $\mathrm{TiO}_{2}$ was used in this study.

Several investigations have been done to elucidate the mechanism of photokilling of Escherichia coli and other bacteria. ${ }^{16-18}$ Sunada et al proposed that decomposition of the outer membrane by photocatalytic reaction ultimately leads to cell death. ${ }^{31}$ Maness et al reached the more specific conclusion that photocatalysis promotes peroxidation of phospholipids in the membrane. ${ }^{19}$ Meanwhile, Matsunaga et al ${ }^{12}$ and Saito et $\mathrm{a}^{20}$ reported a loss of respiratory activity resulting from oxidization of coenzyme A. However, there are few published studies concerning the use of $\mathrm{TiO}_{2}$ for microbial inactivation and focusing on prevention and treatment for pin site infection after external fixation. ${ }^{33} S$. aureus is one of the most common pathogens in percutaneous implant infections and readily mutates into multidrug-resistant forms that can be extremely difficult to treat, eg, Staphylococcus epidermidis, E. coli, and Pseudomonas aeruginosa. ${ }^{9,22-24}$ In this study, we introduced a new method for inhibiting S. aureus infection at percutaneous pin sites based on the photocatalytic bactericidal reactions of $\mathrm{TiO}_{2}$ in a rat model under ultraviolet illumination. In our animal study, the $\mathrm{TiO}_{2}$-coated pin group showed fewer clinical signs of infection and quantitative histomorphometric findings than the untreated pin group. This result indicates that the amount of 


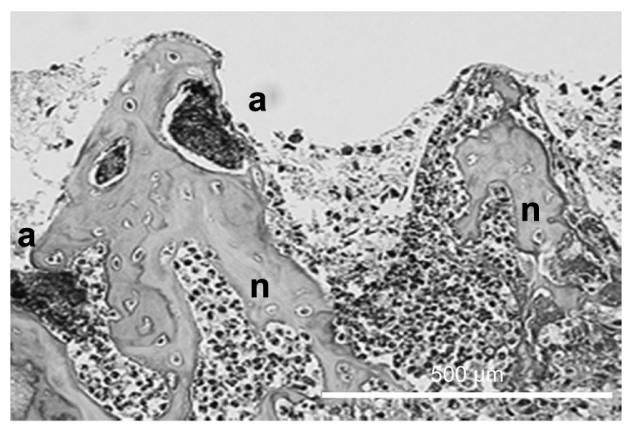

A

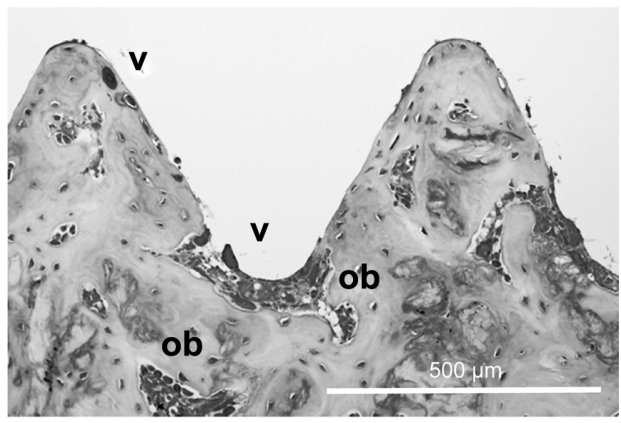

B

Figure 2 Histologic section of bone-pin interface of a control pin (A) and a $\mathrm{TiO}_{2}$-coated pin; (B) many abscesses (a) due to bacteria and neutrophils (n) are seen in the control pin group. There were few findings of bacteria and inflammation, and the screw thread was almost maintained in the $\mathrm{TiO}_{2}$-coated pin group. Osteoblasts (ob) and vascular connective tissue (v) are seen in the bone.

Note: Original magnification $\times 10$ (scale bar $500 \mu \mathrm{m})$.

Abbreviation: $\mathrm{TiO}_{2}$, titanium dioxide.

contaminated bacteria decreased due to the photocatalytic activity of $\mathrm{TiO}_{2} \cdot \mathrm{TiO}_{2}$ pins also had better compatibility with bone tissue and prevented bacterial migration and deep tissue infection in vivo. These findings suggest that photocatalytic $\mathrm{TiO}_{2}$ has the potential to decrease the risk of pin site infection clinically and prevent loosening of the interface between bone and the pin, and that the external fixation pin performs its function effectively.

This study has several limitations. It is known that ultraviolet $\mathrm{A}$ has deleterious effects on bacterial cells, depending on the type of bacteria, the dose of light administered, and degree of bacterial sensitivity. ${ }^{34}$ There was no sign of infection around seven of the 30 untreated pins $(23.3 \%)$ and 19 of the $30 \mathrm{TiO}_{2}$ pins (63.3\%) on clinical evaluation. In our earlier study, ultraviolet A from the same light source had deleterious effects on this type of bacterium. ${ }^{21}$ Therefore, there is no doubt that ultraviolet A killed bacteria in the two groups. However, evidence of significantly fewer signs of infection on clinical and quantitative histomorphometric analysis in the $\mathrm{TiO}_{2}$ group compared with the control group suggests the presence of a photocatalytic bactericidal action against $S$. aureus cells. Another problem is the extended period of ultraviolet A illumination required to suppress pin site infection. Our method of contamination, which was direct inoculation of a large number of bacteria with no

Table 2 Histomorphometric analysis presented as the mean \pm standard deviation

\begin{tabular}{llll}
\hline & $\begin{array}{l}\text { Bone } \\
\text { infection } \\
\text { score (points) }\end{array}$ & $\begin{array}{l}\text { Bone-implant } \\
\text { contact } \\
\text { ratio (\%) }\end{array}$ & $\begin{array}{l}\text { Area of colonies } \\
\text { and neutrophils } \\
\text { (\%) }\end{array}$ \\
\hline Untreated pin & $4.9 \pm 1.0$ & $58.2 \pm 8.1$ & $24.7 \pm 10.3$ \\
$\mathrm{TiO}_{2}$ pin & $3.1 \pm 1.6^{*}$ & $71.4 \pm 5.4^{*}$ & $13.3 \pm 6.4^{*}$ \\
\hline
\end{tabular}

Note: $* P<0.01$. additional treatment given, does not reflect how a percutaneous implant would be infected clinically. Photocatalysts are not particularly useful for breaking down large volumes of bacteria, but they are capable of destroying bacteria as they accumulate. Bactericidal efficacy would be more evident in a clinical situation where appropriate pin care is provided and bacterial exposure is much lower. In this study, ultraviolet A illumination was carried out as a single course only, but we can expect improvement in photocatalytic sterilization activity with multidirectional or multiple illuminations. We acknowledge that the negative effects of ultraviolet rays on the human body pose potential problems in clinical application. The intensity of the black light used in our animal model was $2.0 \mathrm{~mW} / \mathrm{cm}^{2}$, which is as low an intensity as that experienced outdoors. The peak wavelength of ultraviolet $\mathrm{A}$ used in this study was $352 \mathrm{~nm}$. Although ultraviolet A is less harmful than ultraviolet B or ultraviolet $\mathrm{C}$, research is underway to resolve these problems using materials with photocatalytic actions triggered by visible light, so the need to use ultraviolet light will decrease in the near future. ${ }^{35,36}$ Other groups have developed silver composite-type materials in order to maintain long-lasting bactericidal properties, even in dark conditions. ${ }^{37,38}$ However, use of silver in biomaterials or medical devices is still controversial..$^{8-11}$

In this study, we tested and confirmed the efficacy of photocatalytic anatase $\mathrm{TiO}_{2}$ in inhibition of infection associated with external fixation. $\mathrm{TiO}_{2}$ can kill bacteria independent of bacterial strain or antibiotic susceptibility without generating drug-resistant species. Moreover, it has been confirmed that $\mathrm{TiO}_{2}$-coated implants do not prevent osteointegration in a rabbit. ${ }^{29,39}$ Essentially, titanium together with its natural oxide film is known to be bio-inert and to enable bioactivity for osteointegration. For orthopedic surgeons, although such a photocatalytic surface offers 
new and favorable properties from a hygiene point of view, it is very important that there should be no disadvantages in regard to achieving osteointegration. Zhu et al reported that the $\mathrm{TiO}_{2}$ gradient improved corrosion and polarization resistance remarkably, as well as biocompatibility. ${ }^{40}$ Therefore, it can be said that a photocatalytic surface is advantageous for biocompatibility and durability. The high bone-implant contact ratio in the $\mathrm{TiO}_{2}$ pin group might have resulted from inhibition of the influence of infection due to good bone compatibility, as well as from the prevention of destruction or absorption of bone tissue due to bacterial infection. The $\mathrm{TiO}_{2}$ photocatalyst may have important clinical implications for external fixation despite its drawbacks. This simple configuration first-stage study could lead to rewarding results.

\section{Conclusion}

We used a rat model to investigate the ability of photocatalytic $\mathrm{TiO}_{2}$ to inhibit infection at the insertion site of external fixation pins in vivo. Infection was inhibited on the $\mathrm{TiO}_{2}$-coated pins compared with the untreated stainless steel control pins clinically and histomorphometrically. $\mathrm{TiO}_{2}$ has the potential to reduce the pin site infection rates associated with external fixation.

\section{Disclosure}

The authors report no conflicts of interest in this work.

\section{References}

1. Jaskulka RA, Egkher E, Wielke B. Comparison of mechanical performance of three types of unilateral, dynamizable external fixators. Arch Orthop Trauma Surg. 1994;113:271-275.

2. Aro HT, Markel MD, Chao EYS. Cortical bone reaction at the interface of external fixation half-pins under different loading conditions. J Trauma. 1993;35:776-785.

3. Green SA. Complications of external skeletal fixation. Clin Orthop Relat Res. 1983;180:109-116.

4. Green SA, Ripley MS. Chronic osteomyelitis in pin tracts. J Bone Joint Surg Am. 1984;66A:1092-1098.

5. Mahan J, Seligson D, Henry SL, Hynes P, Dobbins J. Factors in pin tract infections. Orthopedics. 1991;14:305-308.

6. Sims M, Saleh M. External fixation - the incidence of pin site infection: a prospective audit. J Orthop Nurs. 2000;4:59-63.

7. Maurer DJ, Merkow RL, Gustilo RB. Infection after intramedullary nailing of severe open tibial fractures initially treated with external fixation. J Bone Joint Surg Am. 1989;71:835-838.

8. Bosetti M, Massè A, Tobin E, Cannas M. Silver coated materials for external fixation devices: in vitro biocompatibility and genotoxicity. Biomaterials. 2002;23:887-892.

9. Massè A, Bruno A, Bosetti M, Biasibetti A, Cannas M, Gallinaro P. Prevention of pin track infection in external fixation with silver coated pins: clinical and microbiological results. J Biomed Mater Res. 2000;53: 600-604.

10. Furno F, Morley KS, Wong B, et al. Silver nanoparticles and polymeric medical devices: a new approach to prevention of infection? J Antimicrob Chemother. 2004;54:1019-1024.
11. Silver S. Bacterial silver resistance: molecular biology and uses and misuses of silver compounds. FEMS Microbiol Rev. 2003;27:341-353.

12. Lucke M, Schmidmaier G, Sadoni S, et al. Gentamicin coating of metallic implants reduces implant-related osteomyelitis in rats. Bone. 2003;32:521-531.

13. Voos K, Rosenberg B, Fagrhi M, Seligson D. Use of a tobramycinimpregnated polymethylmethacrylate pin sleeve for the prevention of pin-tract infection in goats. J Orthop Trauma. 1999;13:98-101.

14. Fujishima A, Rao TN, Tryk DA. Titanium dioxide photocatalysis. J Photochem Photobiol C Photochem Rev. 2000;1:1-21.

15. Michael RH, Scot TM, Won-yong C, Detlef WB. Environmental applications of semiconductor photocatalysis. Chem Rev. 1995;95:69-96.

16. Bekbolet M, Araz CV. Inactivation of Escherichia coli by photocatalytic oxidation. Chemosphere. 1996;32:959-965.

17. Evans P, English T, Hammond D, Pemble ME, Sheel DW. The role of $\mathrm{SiO}_{2}$ barrier layers in determining the structure and photocatalytic activity of $\mathrm{TiO}_{2}$ films deposited on stainless steel. Appl Catal A Gen. 2007;321:140-146.

18. Ibanez JA, Litter MI, Pizarro RA. Photocatalytic bactericidal effect of $\mathrm{TiO}_{2}$ on Enterobacter cloacae: comparative study with other Gram (-) bacteria. J Photochem Photobiol A Chem. 2003;157:81-85.

19. Maness PC, Smolinski S, Blake DM, Huang Z, Wolfrum EJ, Jacoby WA. Bactericidal activity of photocatalytic $\mathrm{TiO}_{2}$ reaction: toward an understanding of its killing mechanism. Appl Environ Microbiol. 1999;65:4094-4098.

20. Saito T, Iwase T, Horie J, Morioka T. Mode of photocatalytic bactericidal action of powdered semiconductor $\mathrm{TiO}_{2}$ on mutans streptococci. J Photochem Photobiol B. 1992;14:369-379.

21. Shiraishi K, Koseki H, Tsurumoto T, et al. Antibacterial metal implant with a $\mathrm{TiO}_{2}$-conferred photocatalytic bactericidal effect against Staphylococcus aureus. Surf Interface Anal. 2008;41:17-22.

22. Arciola CR, Cervellati M, Pirini V, Gamberini S, Montanaro L. Staphylococci in orthopaedic surgical wounds. New Microbiol. 2001;24: 365-369.

23. Chu VH, Crosslin DR, Friedman JY, et al. Staphylococcus aureus bacteremia in patients with prosthetic devices: costs and outcomes. Am J Med. 2005;118:1416.

24. Farr BM. Prevention and control of methicillin-resistant Staphylococcus aureus infections. Curr Opin Infect Dis. 2004;17:317-322.

25. Baba K, Hatada R. Synthesis and properties of $\mathrm{TiO}_{2}$ thin films by plasma source ion implantation. Surf Coat Technol. 2001;136:241-243.

26. Checketts RG, Otterburn M, MacEachern G. Pin track infection: definition, incidence and prevention. J Orthop Trauma. 1993;3 Suppl: $16-18$.

27. Ganser A, Thompson RE, Tami I, Neuhoff D, Steiner A, Ito K. An in vivo experimental comparison of stainless steel and titanium Schanz screws for external fixation. Eur J Trauma. 2007;33:59-68.

28. Petty W, Spanier S, Shuster JJ, Silverthorne C. The influence of skeletal implants on incidence of infection. Experiments in a canine model. J Bone Joint Surg Am. 1985;67:1236-1244.

29. Giavaresi G, Ambrosio L, Battiston GA, et al. Histomorphometric, ultrastructural and microhardness evaluation of the osseointegration of a nanostructured titanium oxide coating by metal-organic chemical vapour deposition: an in vivo study. Biomaterials. 2004;25:5583-5591.

30. Moroni A, Toksvig-Larsen S, Maltarello MC, Orienti L, Stea S, Giannini S. A comparison of hydroxyapatite-coated, titanium-coated, and uncoated tapered external-fixation pins. An in vivo study in sheep. J Bone Joint Surg Am. 1998;80:547-554.

31. Sunada K, Kikuchi Y, Hashimoto K, Fujishima A. Bactericidal and detoxification effects of $\mathrm{TiO}_{2}$ thin film photocatalysts. Environ Sci Technol. 1998;32:726-728.

32. Matsunaga T, Tomoda R, Nakajima T, Wake H. Photoelectrochemical sterilization of microbial cells by semiconductor powders. FEMS Microbiol Lett. 1985;29:211-214

33. Oka Y, Kim WC, Yoshida T, et al. Efficacy of titanium dioxide photocatalyst for inhibition of bacterial colonization on percutaneous implants. J Biomed Mater Res B Appl Biomater. 2008;86:530-540. 
34. Peters J, Jagger J. Inducible repair of near-UV radiation lethal damage in E. coli. Nature. 1981;289:194-195.

35. Arpac E, Sayilkan F, Asiltürk M, Tatar P, Kiraz N, Sayilkan H. Photocatalytic performance of Sn-doped and undoped $\mathrm{TiO}_{2}$ nanostructured thin films under UV and vis-lights. $J$ Hazard Mater. 2007;140: 69-74.

36. Mitoraj D, Jańczyk A, Strus M, et al. Visible light inactivation of bacteria and fungi by modified titanium dioxide. Photochem Photobiol Sci. 2007;6:642-648.

37. Li Y, Leung P, Yao L, Song QW, Newton E. Antimicrobial effect of surgical masks coated with nanoparticles. $J$ Hosp Infect. 2006;62: 58-63.
38. Yao Y, Ohko Y, Sekiguchi Y, Fujishima A, Kubota Y. Self-sterilization using silicone catheters coated with $\mathrm{Ag}$ and $\mathrm{TiO}_{2}$ nanocomposite thin film. J Biomed Mater Res B Appl Biomater. 2007;85:453-460.

39. Sawase T, Wennerberg A, Baba K, et al. Application of oxygen ion implantation to titanium surfaces: effects on surface characteristics, corrosion resistance, and bone response. Clin Implant Dent Relat Res. 2001;3:221-229.

40. Zhu L, Ye X, Tang G, et al. Corrosion test, cell behavior test, and in vivo study of gradient $\mathrm{TiO}_{2}$ layers produced by compound electrochemical oxidation. J Biomed Mater Res A. 2006;78:515-522.
International Journal of Nanomedicine

\section{Publish your work in this journal}

The International Journal of Nanomedicine is an international, peerreviewed journal focusing on the application of nanotechnology in diagnostics, therapeutics, and drug delivery systems throughout the biomedical field. This journal is indexed on PubMed Central, MedLine, CAS, SciSearch ${ }^{\circledR}$, Current Contents ${ }^{\circledR} /$ Clinical Medicine,

\section{Dovepress}

Journal Citation Reports/Science Edition, EMBase, Scopus and the Elsevier Bibliographic databases. The manuscript management system is completely online and includes a very quick and fair peer-review system, which is all easy to use. Visit http://www.dovepress.com/ testimonials.php to read real quotes from published authors.

Submit your manuscript here: http://www.dovepress.com/international-journal-of-nanomedicine-journal 